\title{
Was the Cypress Cluster one of the (Many) Victims of the 1539 - 1543 De Soto Expedition?
}

J. Peter Thurmond

Unknown

Follow this and additional works at: https://scholarworks.sfasu.edu/ita

Part of the American Material Culture Commons, Archaeological Anthropology Commons, Environmental Studies Commons, Other American Studies Commons, Other Arts and Humanities Commons, Other History of Art, Architecture, and Archaeology Commons, and the United States History Commons

Tell us how this article helped you.

This Article is brought to you for free and open access by the Center for Regional Heritage Research at SFA ScholarWorks. It has been accepted for inclusion in Index of Texas Archaeology: Open Access Gray Literature from the Lone Star State by an authorized editor of SFA ScholarWorks. For more information, please contact cdsscholarworks@sfasu.edu. 


\section{Was the Cypress Cluster one of the (Many) Victims of the 1539 - 1543 De Soto Expedition?}

\section{Creative Commons License}

\section{(c) (1) (8)}

This work is licensed under a Creative Commons Attribution-NonCommercial 4.0 International License 


\section{WAS THE CYPRESS CLUSTER ONE OF THE (MANY) VICTIMS OF THE 1539-1543 DE 8OTุO EXPEDITION ?}

\section{J. Peter Thurmond}

In my master's thesis on the archeology of the Cypress creek basin (Thurmond 1981) and a subsequent article in the Bulletin of the Texas Archeological Society (Thurmond 1985), I proposed the identification of a third late prehistoric-protohistoric confederacy for the Caddoan area of northeast Texas, in addition to those of the Hasinai and Kadohadacho. I named the archeological manifestation of this hypothesized sociopolitical entity the Cypress cluster, following a model of late Caddoan sociopolitical organization formulated by Dee Ann Story (Story and Creel 1981). The Cypress cluster is centered geographically on the upper Cypress Creek, White Oak Bayou and Lake Fork Creek basins (Fig. 1). Two sequential temporal units are defined within the Cypress cluster, the Whelan and Titus phases, perhaps dating to the 15th and 16th centuries, respectively. Components of the Titus phase are sufficiently well-documented to permit the identification of four distinct spatial subgroups within the cypress cluster on the basis of their associated ceramic and lithic assemblages. These spatial subgroups are termed subclusters (the Three Basins, Tankersley Creek, Swauano Creek and Big Cypress Creek subclusters), and probably represent the archeological remains of four affiliated tribal groups.

I have previously suggested that the failure of ethnographers to recognize the Cypress cluster might reflect its position off the beaten path, in the uplands far to the west of the Red River and off the most direct route between the Kadohadacho in the Great Bend region and the Hasinai in the upper Neches/Angelina basins (Thurmond 1981, 1985). Both of the latter groups were initially recorded by the De soto expedition in 1542 (Swanton 1939, 1942), and were fairly well documented during the 1700s due to Spanish missionizing of the Hasinai and French trading with the Kadohadacho. However, I have never liked negative evidence arguments, and I have always been uncomfortable with the concept that the Cypress cluster was simply "bypassed" in the late 1600s and early 1700s.

Continued research into the route and effects of the 15391543 De Soto expedition across the southeastern United States (cf. Brain 1985; Hudson 1985, 1986, 1988; Schambach 1989) has provided the evidence for a more tenable explanation of the absence of the cypress cluster from seventeenth and eighteenth century European accounts. Reconstruction of the route through northeast Texas and the locations of aboriginal groups encountered have always been problematic, as the most detailed account (the Ranjel narrative) terminates in central Arkansas. The expedition was on its last leg by the time it reached Texas, and was moving about erratically (Schambach 1989: 10). The most recent reconstruction (Schambach 1989: Fig. 2) of the route of De Soto's 
army through northeast Texas in 1542 (by then under the command of Luis de Moscoso, following De Soto's death in Arkansas) indicates the party crossed through the center of the Cypress cluster (Fig. 1), probably following an ancient aboriginal trail variously known in historic times as the Hasinai Trace, the cherokee Trace or Trammell's Trace, which apparently crossed Big Cypress Creek in the vicinity of Benson's Crossing (Wedel 1978: 3; Perttula et al. 1986: 184; Russell 1965). Far from being off the beaten path, it appears that the Cypress cluster sat astride a major overland route between the Kadohadacho and Hasinai confederacies.

Both Hudson (1986) and Schambach (1988: 20, 25, Fig. 2) believe that the Lacane, which Moscoso encountered in traveling between the Kadohadacho and Hasinai areas, were located in the upper Cypress basin. If so, identification with the Titus phase of the Cypress cluster seems certain, although Schambach does not make this specific connection. He does however explicitly identify the Belcher phase as the archeological manifestation of the "Naguatex chiefdom" encountered by the expedition on the Red River (ibid.: 20-23), and suggests that the Texarkana phase likewise equates with the Nissohone/Amaye on the Sulphur and Red rivers, upstream of the Belcher phase sites. Turner (1978: 98100) offers a possible confirmation of the passage of the De Soto expedition through the Cypress cluster, noting the occurrence of "chalice-like" stemmed vessels and spoon-like ceramic ladles at the Titus phase components $41 \mathrm{CP} 5,41 \mathrm{CP} 12$ and $41 \mathrm{FK} 4$, straddling Schambach's proposed route through the area (Fig. 1). Turner suggests that these forms, which do not seem to occur in whelan phase or earlier contexts within the basin, were modeled after Spanish stemmed glasses and spoons observed by the Cypress cluster inhabitants during the passage of the expedition.

There is very little evidence that the Titus phase components of the cypress cluster extend into the early historic period, much past A.D. 1600. Glass beads were reportedly recovered by a private collector from the Titus phase cemetery at the Tracy site (41CP71) in the Big Cypress Creek subcluster, but the beads were apparently from the surface of the site, and were not demonstrably associated with the Titus phase component (R.I. Turner, p.c.). Within the Three Basins subcluster, the wichita types Womack Engraved and Womack Plain have been recovered in burial association with Titus phase ceramics at $41 \mathrm{HPl}$, the Culpepper site (Scurlock 1962) and at 41TT2, the W.A. Ford site (Thurmond 1981). Given the massive number of Titus phase graves that have been excavated to date, by now we would surely have encountered examples containing significant quantities of European trade goods if such were present.

On the basis of the foregoing, I think we must now assume that the Cypress cluster existed as a viable entity at the time of the 1542 Spanish incursion, but that the area had been virtually abandoned before the inception of significant Caddoan-European interaction in northeast Texas in the late 1600s. The apparent interaction with the wichita indicated at Culpepper and Ford 
is at first glance puzzling, given the 18th century dates of the closest recorded Wichita components at Pearson (41RA5, Duffield and Jelks 1961) and Gilbert (41RA13, Jelks 1966), but it has been suggested that the Wichita may have been well south of the Red River before 1650 (Duffield and Jelks 1961: 74).

So what happened to these people after 1542? It is apparent that the passage of the De soto expedition through the southeast was disruptive to an extreme (Dobyns 1983; Perttula et al. 1986: 186-189; Dye 1989; Murray 1989:49). Treatment of the aboriginal groups encountered was brutal, with many casualties in battle (or massacre), and the Spaniards subsisted by pillage. A more lasting and pernicious effect was the microbial baggage the spaniards carried with them: chicken pox, smallpox, malaria, measles and typhoid fever. Lacking immunity to these heretofore unknown diseases, the Native American populations were devastated by epidemics following the passage of De Soto's army. Perttula (with others 1986: 187) has suggested that Caddoan groups in northeast Texas experienced a resultant process of severe and ongoing population decline after 1542, accompanied by the depopulation of many areas and the consolidation of the survivors into a smaller number of sociopolitical entities.

It is therefore entirely possible that the Cypress cluster fell victim to the De Soto expedition, in that epidemic disease so devastated the population as to result in the abandonment of the area, probably by the mid-1600s. It is likely that the survivors gravitated to surviving communities in the Hasinai and Kadohadacho areas, although the components at Culpepper and Ford suggest that some of the Three Basins subcluster population interacted with wichita groups to the west, and may have been drawn out onto the plains. Swanton (1939) equated the Lacane of the 1500s with the northern Hasinai Nacao of the 1700s, and it is possible that the Nacao represent remnants of Cypress cluster groups which moved south of the Sabine in the 1600 s to join the Hasinai confederacy. By the early 1700s, it would appear that the depopulation of the cypress cluster territory was complete (Bolton 1908: 251).

Comments from anyone having thoughts or data pertinent to the fate of the Cypress cluster populace in the $16 \mathrm{th}$ and $17 \mathrm{th}$ centuries would be greatly appreciated. In particular, if Titus phase cemeteries or settlements occur in which there are definite associations with European trade goods, these need to be recorded, documented and reported. Anyone having such information is encouraged to write to the author at P.O. Box 374 , Leedey, OK 73654. If you have a collection from a pertinent site, I would be more than willing to come to you in order to photograph it. My phone number is (405) 488-2127. The foregoing has been abstracted from an updated version of my master's thesis under preparation for publication by the Texas Archeological Research Laboratory, University of Texas at Austin. This article has been submitted to Caddoan Archeology in hope of soliciting some reader response. 


\section{REFERENCES CITED}

Bolton, Herbert $\mathrm{E}$.

1908 The Native Tribes about the East Texas Missions. Texas state Historical Association Quarterly 11: 249-276.

Brain, Jeffrey P.

1985 Update of De Soto Studies since the United States De Soto Commission Report. In Final Report of the United states De soto Expedition Commission by John R. Swanton, pp. xi-xxii, 1985 reprint by the Smithsonian Institution Press, Classics in Anthropology Series. Washington, D.C.

Dobyns, Henry E.

1983 Their Numbers Became Thinned: Native American Population Dynamics in Eastern North America. The University of Tennessee Press. Knoxville.

Duffield, Lathel F. and Edward B. Jelks

1961 The Pearson Site, A Historic Indian Site at Iron Bridge Reservoir, Rains County, Texas. The University of Texas at Austin, Department of Anthropology, Archaeology series 4.

Dye, David $\mathrm{H}$.

1989 Death March of Hernando De Soto. Archaeology 42(3): 26-31.

Hudson, Charles

1985 De Soto in Arkansas: A Brief Synopsis. Arkansas Archeological society Field Notes 205: 3-12.

1986 Hernando De Soto in the Caddo Area. Paper presented at the 28th Caddo Conference, Little Rock, Arkansas.

1989 Tracking the Elusive De Soto. Archaeology $42(3): 32-36$.

Jelks, Edward B.

1966 The Gilbert Site: A Norteño Focus Site in Northeastern Texas. Bulletin of the Texas Archeological society 37 .

Murray, Katherine

1989 Bioarcheology of the Parkin site, Cross County, Arkansas. The Arkansas Archeologist 27/28: 49-62.

Perttula, Timothy K., Bob D. Skiles, Michael B. Collins, Margaret C. Trachte and Fred Valdez, Jr.

1986 "This Everlasting Sand Bed": Cultural Resources Investigations at the Texas Big Sandy Project, Wood and Upshur Counties, Texas. Prewitt and Associates, Inc., Reports of Investigations 52 .

Russell, Traylor

1965 History of Titus County. W.H. Morrison, Bookseller. Waco. 
Schambach, Frank F.

1989 The End of the Trail: The Route of Hernando De Soto's Army through Southwest Arkansas and East Texas. The Arkansas Archeologist 27/28: 9-34.

Scurlock, J. Dan

1962 The Culpepper Site: A Late Fulton Aspect Site in Northeastern Texas. Bulletin of the Texas Archeological society 32 : 285-316.

Story, Dee Ann and Darrell G. Creel

1981 The Cultural setting. In "The Deshazo site, Nacogdoches County, Texas, Volume 1", pp. 20-34. Texas Antiquities Committee, Texas Antiquities permit series 7 .

Swanton, John R.

1939 Final Report of the United States De Soto Expedition Commission. United States Government Printing office, House Document 71 .

1942 Source Material on the History and Ethnology of the Caddo Indians. Smithsonian Institution, Bureau of American Ethnology Bulletin 132 .

Thurmond, J. Peter

1981 Archeology of the Cypress Creek Drainage Basin, Northeastern Texas and Northwestern Louisiana. M.A. Thesis. The University of Texas at Austin.

1985 Late Caddoan Social Group Identifications and Sociopolitical organization in the Upper Cypress Basin and Vicinity, Northeastern Texas. Bulletin of the Texas Archeological Bociety 54: $185-200$.

Turner, Robert L.

1978 The Tuck Carpenter site and Its Relation to other sites within the Titus Focus. Bulletin of the Texas Archeological society 49: 1-110.

Wedel, Mildred $\mathbf{M}$.

1978 La Harpe's 1719 Post on Red River and Nearby Caddo Settlements. The University of Texas at Austin, Texas Memorial Museum Bulletin 30 . 


\section{FIGURE 1 \\ 8UBCLUSTER ASSOCIATIONS OF THE TITUS PHASE COMPONENTS}

The distribution of the recorded components of the cypress cluster during the 16 th century Titus phase is illustrated. The components are classified into the four subclusters identified to date for the Titus phase. It is believed that the Cypress cluster represents a third late prehistoric Caddoan confederacy for northeast Texas, and that the subclusters represent component tribes. The 1542 route of De Soto's army under the direction of Luis de Moscoso as hypothesized by Frank Schambach (1989) is shown. The three circled components (41FK4, 41CP5 and 41CP12) are those which have yielded stemmed ceramic vessels and ceramic spoons which R.L. Turner (1978) believes may be native copies of spanish items observed when the Spanish army passed through the area. 


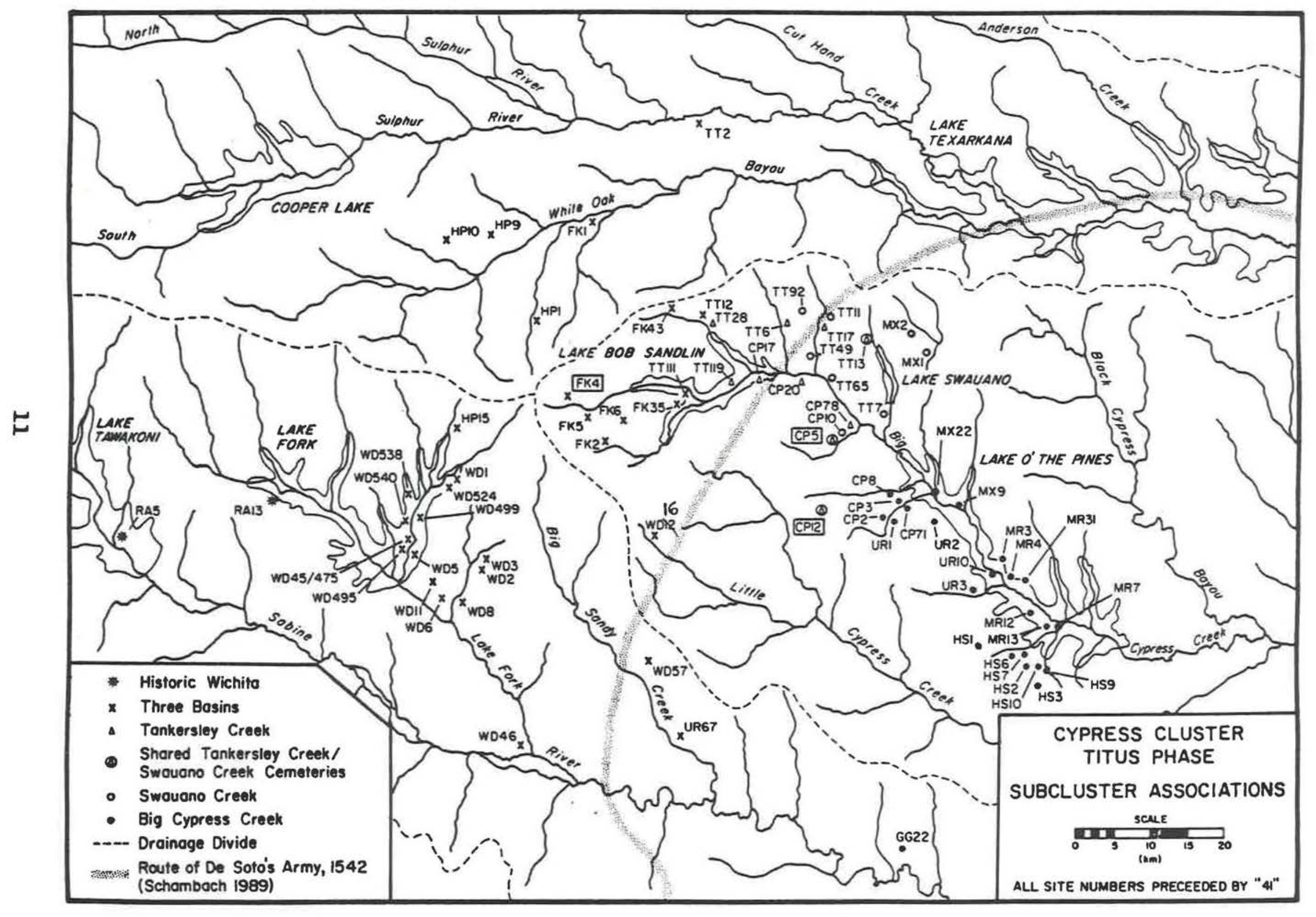

